\title{
Voting Rights and the Constitution: The Disenfranchisement of Non-English Speaking Citizens
}

\author{
Sandra Guerra
}

In 1980, more than twenty-three million Americans spoke languages other than English in their homes. ${ }^{1}$ Most non-English speaking Americans are native-born citizens, who have a constitutional right to vote. Yet before the enactment of the 1975 amendments to the Voting Rights Act, which require multilingual voting assistance ${ }^{2}$ in areas with large numbers of non-English speakers, ${ }^{3}$ people who did not understand English were effectively disenfranchised by elections held only in English.

These multilingual election provisions of the Voting Rights Act, however, do not sufficiently guarantee non-English speaking citizens' right to vote. The language of the statute, as well as its implementation, have limited the reach of this federal statutory right. ${ }^{4}$ Some localities supplement the Voting Rights Act protection through state and local multilingual voting legislation. ${ }^{\text {B }}$ However, political organizations in many states currently are promoting state constitutional amendments, commonly referred to as "English Language Amendments," which would designate English as the official language of those states. ${ }^{\circ}$ Critics of the "English-only" movement anticipate that states will attempt to use these amendments to bar the provision of multilingual voting assistance except as required by the Voting Rights Act. ${ }^{7}$ That the voting rights of non-English speakers are

1. See Bureau of the Census, U.S. Dep't of Commerce, Statistical Abstract of the UNITED STATES 34 (1986).

2. Throughout this Note, "voting assistance" refers to all written and oral assistance, including the provision of multilingual ballots.

3. The 1975 amendments to the Voting Rights Act of 1965, 42 U.S.G. § 1973b(f)(4) (1982), provide that, in any jurisdiction covered by the Act, "[w]henever any fjurisdiction] . . provides any registration or voting notices, forms, instructions, assistance, or other materials or information relating to the electoral process, including ballots," it shall provide them on a multilingual basis to members of applicable language minority groups.

4. See infra note 26.

5. See infra note 30 .

6. N.Y. Times, Jan. 17, 1987, at A7, col. 2. Efforts to amend the federal constitution also persist. See, e.g., Note, The Proposed English Language Amendment: Shield or Sword?, 3 Yale L. \& PoL'y REv. 519, 519 (1985); Note, Language Minority Voting Rights and the English Language Amendment, 14 Hastings Const. L.Q. 657 (1987).

7. The proponents of the English language amendments, spearheaded by a national group, U.S. English, are opposed to multilingual elections, whether mandated by federal or state law. See ENGLISH UNITES Us (California campaign pamphlet) (on file with author); U.S. ENGLISH, FACT SHEET: 
threatened by the English-only movement starkly reveals the inadequacies of the Voting Rights Act as the sole guarantor of non-English speakers' right to vote.

This Note argues that because voting is a specially protected fundamental right, the equal protection clause of the Fourteenth Amendment guarantees that absent compelling justification states may not provide voting assistance to English speakers without also providing equivalent assistance to non-English speakers. Ensuring this right fully will require a judicial determination that the Constitution requires states to provide multilingual voting assistance for non-English speakers-a position that courts have yet to adopt fully.

Section I of the Note will address the interplay between the judiciary and Congress in the development of multilingual voting rights and will expose the shortcomings of the current federal statutory scheme. Section II sets forth a constitutional argument for a right to multilingual voting assistance. Section III provides tentative policy suggestions for Congressional improvement of the Voting Rights Act multilingual election provisions.

\section{The Development of Federal Protection of Non-English SPEAKERs' Right to Vote}

\section{A. The 1965 Voting Rights Act: Origins of Federal Protection}

The restrictive reading of constitutionally protected voting rights in the United States Supreme Court's 1959 decision in Lassiter $v$. Northhampton County Board of Elections ${ }^{8}$ prompted Congress to enact the Voting Rights Act of $1965^{\circ}$ The far-reaching provisions of the 1965 legislation were designed to eliminate literacy tests and other discriminatory "tests and devices" that effectively disenfranchised blacks in the South. ${ }^{10}$ Thus, the 1965 Voting Rights Act secured the right to vote for

Bilingual Voting Ballots (1986) (on file with author); N.Y. Times, Feb. 22, 1987, at 23 CN 1, col. 1; see also Note, "Official English": Federal Limits on Efforts to Curtail Bilingual Services in the States, 100 HaRv. L. REv. 1345, 1345-47 (1987).

8. 360 U.S. 45 (1959). In Lassiter, the Supreme Court upheld the use of English literacy tests as a means of qualifying voters in North Carolina, despite the fact that literacy tests effectively eliminated a large segment of the black voting constituency. The Court found that absent invidious discrimination the states could limit the franchise to literate persons "to promote intelligent use of the ballot." Id. at 51 .

A lower federal court decision extended the logic of Lassiter to require literacy specifically in English. Mexican-American Federation-Washington State v. Naff, 299 F. Supp. 587 (E.D. Wash. 1969), vacated and remanded sub nom., Jimenez v. Naff, 400 U.S. 986 (1971) (vacated in light of Oregon v. Mitchell, 400 U.S. 112 (1970), which upheld Voting Rights Act literacy test ban). For a criticism of Naff's misinterpretation of both Lassiter and the stricter post-Lassiter standard of review, see Note, Constitutional Law-Voting Rights-State English Literacy Requirement Upheld, 45 WASH. L. REv. 401 (1970).

9. Pub. L. No. 89-110, 79 Stat. 437 (codified at 42 U.S.C. $\$ \S 1971,1973$ (1982)).

10. In 1975 , Congress made the literacy test ban permanent. See S. REP. No. 295, 94th Cong., 1st Sess. 8, reprinted in 1975 U.S. CodE Cong. \& ADMIN. News 774 [hereinafter 1975 S. Rep.]; see also H.R. ReP. No. 439, 89th Cong., 1st Sess. 12-13, reprinted in 1965 U.S. Code ConG. \& ADMIN. NEws 2437, 2443-44. 
English illiterates, a right that the Supreme Court had not been willing to require as a constitutional matter. ${ }^{11}$

The 1965 statute also included a provision that recognized the need for multilingual assistance for non-English speakers. It barred language discrimination at the polls for literate Spanish-speaking Puerto Rican voters who emigrate to the mainland. ${ }^{12}$

The Voting Rights Act, in turn, has been consistently upheld by the Supreme Court. ${ }^{13}$ The two most important Supreme Court opinions relating to the question of non-English speaking voters are the majority opinion in Katzenbach v. Morgan ${ }^{14}$ and Justice Douglas' dissent in Cardona v. Power. ${ }^{15}$ Although they address the legality of imposing English literacy requirements on non-English speaking voters, these opinions also provide a strong legal rationale for the requirement of state multilingual voting assistance. The Morgan opinion represented a significant shift in the Court's tolerance for voting devices that exclude non-English speakers:

We are told that New York's English literacy requirement originated in the desire to provide an incentive for non-English speaking immigrants to learn the English language and in order to assure the intelligent exercise of the franchise. Yet Congress might well have questioned, in light of the many exemptions provided, and some evidence suggesting that prejudice played a prominent role in the enactment of the requirement, whether these were actually the interests being served. Congress might have also questioned whether denial of a right deemed so precious and fundamental in our society was a necessary or appropriate means of encouraging persons to learn English, or of furthering the goal of an intelligent exercise of the franchise. ${ }^{16}$

Justice Douglas' dissenting opinion in Cardona .v. Power ${ }^{17}$ is also important as one of the few judicial pronouncements on the constitutional issues raised by voting in a multilingual society. Justice Douglas, who wrote the opinion for the Court in Lassiter, found that the Fourteenth Amendment prohibited discrimination among literate persons, ${ }^{18}$ as is the

11. Professor Tribe predicts that literacy tests would most likely be overturned on constitutional grounds given that Lassiter antedates the use of strict scrutiny when fundamental rights such as voting are implicated. L. Tribe, American Constitutional. LAw § 13-15, at 1093 (2d ed. 1988).

12. See 42 U.S.C. $\S 1973 b(e)$ (1982).

13. See South Carolina v. Katzenbach, 383 U.S. 301 (1966) (upholding Voting Rights Act of 1965 under $\$ 2$ of the Fifteenth Amendement); Katzenbach v. Morgan, 384 U.S. 641 (1966) (upholding under $\S 5$ of the Fourteenth Amendment provision [§ 4(e)] of the Voting Rights Act which protects Puerto Rican voters).

14. 384 U.S. 641 (1966).

15. 384 U.S. 672, 675 (1966) (Douglas, J., dissenting).

16. Katzenbach, 384 U.S. at 654 .

17. Cardona, 384 U.S. at 675 (Douglas, J., dissenting).

18. Id. 
case when English literacy tests are applied to Spanish-speaking literate persons. ${ }^{19}$ He wrote:

The heavier burden [of an English literacy requirement] which New York has placed on the Spanish-speaking American cannot . . . be sustained under the Equal Protection Clause of the Fourteenth Amendment. . . . [T]here is no rational basis-considering the importance of the right at stake-for denying those with equivalent qualifications except that the language is Spanish. ${ }^{20}$

Thus, prior to the enactment of the 1975 legislation which provides more extensive multilingual voting assistance, Congress and the Supreme Court had begun to recognize that a non-English speaker's right to vote is violated when elections are held only in English. Morgan and the Cardona dissent perceived that government action short of an absolute denial of the vote can effectively disenfranchise electors.

\section{B. The 1975 Amendments: A Federal Right to Multilingual Voting Assistance}

In response to overwhelming evidence of discrimination in voting directed against racial and ethnic minority non-English speakers, ${ }^{21}$ Congress enacted the 1975 amendments to the Voting Rights Act of $1965 .{ }^{22}$ The 1975 Amendments created a multilingual voting system that has brought about a significant increase in voter participation ${ }^{23}$ by non-English speak-

19. The plaintiff in Cardona was a Spanish-speaking Puerto Rican voter who sought a judicial declaration that the New York English literacy requirement, as applied to her, denied her right to vote under the Federal Constitution. Id. at 673.

The majority opinion held that the record did not indicate whether the plaintiff was literate in Spanish. If she were, the case would be covered by $\S 4(\mathrm{e})$ of the Voting Rights Act of 1965 and would therefore be moot. Because the New York courts did not determine whether the federal statute applied, the Court vacated and remanded the cause of action. Id. at 674 .

20. Id. at 676; see also Cox, The Supreme Court, 1965 Term-Foreword: Constitutional Adjudication and the Promotion of Human Rights, 80 HARv. L. REv. 91, 96-97 (discussing Justice Douglas' Cardona dissent).

21. Only language minorities that are also racial and ethnic minorities are protected by the Voting Rights Act. 42 U.S.C. $\S 1973 \mathrm{aa}-1 \mathrm{a}$ (e). The list of groups as specified by the Bureau of the Census includes the following: Japanese, Chinese, Filipino, Korean, Vietnamese, Asian-Indian, Spanish/Hispanic, American Indian, Eskimo, Aleut and Hawaiian. See Bureau of the Census, Directions for Determining Coverage under Voting Rights Act, 1982, Attachment A3 (Aug. 13, 1984) (on file with author).

22. The 1975 Amendments require certain jurisdictions to provide all voting assistance, oral and/ or written, on a multilingual basis. See 42 U.S.C. \$ $1973 \mathrm{~b}(\mathrm{f})(4)$. The 1975 amendments also make permanent a nationwide ban on literacy tests and other discriminatory tests or devices. The definition of "test or device" was expanded in 1975 to include English-only elections where large numbers of language minority persons live. See 1975 S. REP., supra note 10.

23. Voting should be encouraged, particularly in light of the tragically low voter turnout in this country. See J. Cohen \& J. Rogers, On Democracy 32-33 (1983). On election day in 1980, the $53.2 \%$ turnout was the third lowest in American history. Id. at 33. Turnout rates for "off-year" congressional elections are even lower. In 1982 only 35.7 percent of the eligible electorate went to the polls. Id. 
ers and enhanced their political influence in their communities. ${ }^{24}$ However, the Act has proven inadequate to fully safeguard the constitutional rights of non-English speakers.

The 1975 Amendments mandate the use of multilingual ballots in areas that meet certain requirements. ${ }^{25}$ The determinative requirement has proven to be that five percent of the eligible voters belong to a single language minority. ${ }^{28}$ In 1980, 386 jurisdictions (most jurisdictions are counties or towns) were determined to meet the requisite five percent figure. ${ }^{27}$ Although the Act covers a large number of jurisdictions, the use of a trigger calculated as a percentage of the voting population is problematic. Jurisdictions with millions of voters can deny multilingual voting assistance to tens of thousands of non-English speakers so long as they fall below the five percent threshold. ${ }^{28}$

Furthermore, the Act only protects certain racial and ethnic minorities. Given the past discrimination against these groups in voting, it is understandable that Congress especially concern itself with the protection of racial and ethnic groups. Nonetheless, all non-English speakers, regardless of race or ethnicity, are effectively disenfranchised by elections held only in English. The voting rights of all non-English speaking American citizens are infringed when the state denies voting assistance in a language they can understand. ${ }^{29}$

The inadequacy of the Act has led some jurisdictions with large concentrations of non-English speakers that fall outside federal statutory coverage (such as Los Angeles, San Francisco, and San Diego) to provide mul-

24. R. BRISChetto, Bilingual Elections at WORK IN THE Southwest 62-177 (1982).

25. Jurisdictions may be covered under the Voting Rights Act of 1975, 42 U.S.C. $\S 1973 b(f)(4)$ (1982) or Pub. L. No. 94-73, §203(c). Under section $b(f)(4)$, a jurisdiction is covered if over five percent of the voting-age citizens are members of a single language minority group and if the previous presidential election was conducted only in English and less than fifty percent of voting-age citizens were registered. Section 203(c) also requires that more than five percent of voting-age citizens belong to a single language minority group. Coverage is triggered under this provision if either the jurisdiction-wide or statewide illiteracy rate exceeds the national rate. See General Accounting Office, Bilingual. Voting Assistance: Costs of and Use During the November 1984 General. ELECTION (1986) [hereinafter GAO REPORT].

26. The Justice Department and Bureau of the Census have interpreted a 1982 amendment to the Voting Rights Act to change the methodology used to determine whether a person belongs to a language minority group. See Reynolds, New Coverage Determinations Under $\S 203$ of the Voting Rights Act 27-28 (May 11, 1984) (Justice Dep't Memorandum) (on file with author). As a result of the change, over $56 \%$ of the jurisdictions that would have been covered in 1984 were not covered. $\mathrm{K}$. Hall, Chairwoman, U.S. Judiciary Subcommittee on Census and Population \& D. Edwards, Chairman, U.S. Judiciary Subcommittee on Civil and Constitutional Rights, Letter to the Bureau of the Census (Aug. 29, 1984) (on file with author).

27. After the methodology change in 1982 , see supra note 26 , many cities with large language minority populations were dropped from the Act's coverage. Compare 28 C.F.R. $\S 55$ app. (1980) with Voting Rights Act Amendments of 1982, 49 Fed. Reg. 25,887 (1984).

28. For example, Los Angeles, San Francisco, and San Diego, do not meet the requisite five percent figure. These cities are so large that despite the fact that a city like Los Angeles had roughly 69,000 Spanish monolinguals in 1984, they do not total five percent of the population. See Reynolds, supra note 26 , at 27 . On the other hand, a city of 100,000 need have only 5,000 non-English speakers to trigger the Act.

29. See infra Section II. 
tilingual ballots even though not required to do so under the Act. Additionally, some states have laws that supplement the requirements of the Voting Rights Act. ${ }^{30}$ However, English-only supporters in several states are currently aiming to prohibit this local action. ${ }^{31}$

The 1975 Voting Rights Act amendments were a major step forward in allowing most language minorities to vote unhindered by language barriers. The current political trend, however, reveals the limitations of the Act. The voluntary provision of multilingual ballots in areas outside the reach of the Voting Rights Act is threatened by English language amendments. The extent to which non-English speakers have a constitutionally protected right to multilingual voting assistance has yet to be judicially determined. The following section develops an argument for the full vindication of non-English speakers' right to vote.

\section{Multilingual Voting Assistance and the Constitutional RIGHT TO Vote}

The Constitution gives the states the authority to regulate elections subject to the power of Congress to override state regulations. ${ }^{32}$ Both state and federal regulations are required to meet constitutional standards. In articulating constitutional norms in the voting rights area, the Supreme Court has relied primarily on the equal protection clause of the Fourteenth Amendment. The Supreme Court has employed a "strict scrutiny" standard of review ${ }^{33}$ in cases implicating fundamental rights, ${ }^{34}$ such as the

30. See, e.g., MAss. GEN. LAws ANN. ch. 51, $\$ 36$ (West Supp. 1988) (providing that registration affidavits must be in Spanish for Spanish speakers); LA. REv. STAT. ANN. \$18:106 (West Supp. 1988) (interpreters provided for persons who do not speak, read, or write English); N.M. STAT. ANN. ch. 1 arts. 1J-19, 2-5, 4J-15, 8-10, 10-3, 11-14, 12-12, 16-8 (West Supp. 1986) (providing for elections conducted entirely in both Spanish and English).

31. Voter-initiated referendums to declare English the official language of a state have been proposed or are being considered in 33 states, and 13 have adopted them. N.Y. Times, Aug. 2, 1987, at A32, col. 1; N.Y. Times, Feb. 22, 1987, at $\$ 11$, p. 1, col. 1 .

32. Article I, section 4 of the Constitution has been interpreted by the Supreme Court to invest Congress with broad power to regulate the entire area of voting practices by the states in federal elections. See L. TRIBE, supra note $11, \S 13-10$, at 1084-85. When states employ voting practices that contravene Fourteenth Amendment guarantees, Congress may act in pursuance of its enforcement powers in $\S 5$ to regulate both federal and state elections.

33. The Supreme Court applies a "strict scrutiny" standard of review to classifications that infringe rights considered "fundamental" or classifications singling out "suspect classes," which are limited to race or national-origin groups. See L. TRIBE, supra note 11, § 16-6, at 1451-54. An intermediate level of scrutiny is applied to classifications that implicate the rights of "quasi-suspect" groups, such as classifications on the basis of sex or physical disabilities. Id. $\S 16-33$, at 1610-18. Classifications that do not implicate either specially protected rights or specially protected persons are granted broad deference by the courts under a third standard of review, the "rational basis" standard. Id. $\S 16-2$, at $1439-43$.

34. The Court has identified a number of fundamental rights in addition to the right to vote, including, for example, procreation, Skinner v. Oklahoma ex rel. Williamson, 316 U.S. 535, 541 (1942); rights with respect to criminal procedure, see, e.g., Griffin v. Illinois, 351 U.S. 12, 17 (1956); the right to travel, Shapiro v. Thompson, 394 U.S. 618, 630 (1969). 
right to vote. ${ }^{35}$ The government classification will be upheld only if it is the "least restrictive means" of promoting a "compelling" state interest. ${ }^{36}$

This Note argues that elections held only in English effectively deny a fundamental right of non-English speakers. A state's preference in favor of English-speaking voters is, thus, unequal treatment that should trigger strict scrutiny review. ${ }^{87}$

\section{A. Strict Scrutiny of Fundamental Rights}

Political minorities have long used the equal protection clause to obtain judicial protection from majoritarian legislative processes that tend to discount their interests. ${ }^{38}$ In scrutinizing infringements of fundamental rights, courts show less than usual deference to legislative judgments in several respects. First, courts have ruled that state action violates the equal protection clause even if it causes an effective, but not an absolute, infringement of a fundamental right. ${ }^{30}$ The equal protection clause is also violated whenever state action gives preference to the exercise of the fundamental rights of some and not others, when it burdens the exercise of those rights for some but not for others, or when it penalizes some individuals who choose to exercise their constitutional rights. ${ }^{40}$

35. Non-English speakers have never been considered a "suspect class" per se. Thus, their claims have not received strict scrutiny review. See, e.g., Soberal-Perez v. Heckler, 717 F.2d 36, 41 (2d Cir. 1983) (rejecting plaintiff's challenge to English-only Social Security notices), cert. denied, 466 U.S. 929 (1984); Guadalupe Org. v. Tempe Elem. School Dist. No. 3, 587 F.2d 1022 (9th Cir. 1978) (rejecting plaintiffs' claim to a constitutional and statutory right to bilingual education). However, since the vast majority of non-English speaking persons in this country are members of racial or ethnic minorities, non-English speakers are in most cases a directly derivative group of a clearly suspect class. Hence, in cases where plaintiffs can prove an intent to discriminate against them on the basis of their race or national origin, and not simply on account of their language, the courts should apply strict scrutiny. See supra note 33.

More recently, courts have been more receptive to the argument that one's language and one's national origin are closely related. See, e.g., Olagues v. Russoniello, 797 F.2d 1511, 1520-21 (9th Cir. 1986) (en banc) (strict scrutiny triggered where Spanish-speaking and Chinese-speaking voters targeted for voter fraud investigation), vacated as moot, $108 \mathrm{~S}$. Ct. 52 (1987).

Should a court find that neither the fundamental rights strand nor the suspect class strand trigger strict scrutiny, the court should at the very least apply an intermediate level of scrutiny accorded "quasi-suspect classes." See supra note 33; see also Note, supra note 7 at 1354; Note, Quasi-Suspect Classes and Proof of Discriminatory Intent: A New Model, 90 Y ALE L.J. 912 (1981) (using language minorities as model of quasi-suspect group).

36. See San Antonio Indep. School Dist. v. Rodriguez, 411 U.S. 1, 16-17 (1973).

37. Recognition that restrictions on multilingual ballots implicate the fundamental right to vote, triggering the most exacting judicial scrutiny, is an essential part of any equal protection analysis on voting rights. An analysis that categorizes the provision of ballots together with other state "bilingual programs" fails to take into account the constitutionally elevated status of voting rights. See Note, supra note 7, at 1352.

38. See J. Ely, Democracy and Distrust 135-36 (1980).

39. See, e.g., Griffin v. Illinois, 351 U.S. 12, 18 (1956) ("There is no meaningful distinction between a rule which would [absolutely] deny the poor the right to defend themselves in a trial court and one which effectively denies the poor an adequate appellate review accorded to all who have money enough to pay the costs in advance."); see also infra notes 56-57 and accompanying text.

40. See, e.g., Memorial Hosp. v. Maricopa County, 415 U.S. 250, 257-58 (1974) (state may not penalize right to travel); Garza v. Smith, 320 F. Supp. 131 (W.D. Tex. 1970) (statute allowing voting assistance only to physically handicapped gave preference to physically handicapped over illiterate voters); Smith v. Arkansas, 385 F. Supp. 703, 704-05 (E.D. Ark. 1974) (candidate write-in statute 
Once a court is satisfied that a legislative action violates a fundamental right, it will apply a strict scrutiny standard of review which requires the state to show that the action is necessary to advance a legitimate compelling state interest and the means employed are the "least retrictive" ones available.

\section{Voting is Fundamental}

The Supreme Court has long recognized "the political franchise of voting" to be a "fundamental political right, because preservative of all rights." ${ }^{41}$ While the Constitution does not explicitly protect this right, ${ }^{\mathbf{4 2}}$ the Court has repeatedly held that as a fundamental right, voting has a special place within constitutional framework..$^{43}$ Substantively, the Court's decisions have found the right to vote to encompass the right "to participate in state elections on an equal basis with other qualified voters whenever the State has adopted an elective process for determining who will represent any segment of the state's population. . .".44 Accordingly, the Court has provided judicial relief to citizens who are denied their voting rights by discriminatory devices. ${ }^{45}$

\section{Unequal Provision of Voting Rights}

\section{a. Differing Treatment}

The equal protection clause prohibits states from treating voters in like circumstances differently. Some might argue, however, that the equal protection clause does not require affirmative action by the states: that is, it prohibits discrimination but does not require states to provide special benefits. ${ }^{46}$ However, such an argument misstates the real issue raised by Eng-

unconstitutional as unreasonable and unjustified burden on voting rights of illiterate voters).

41. Yick Wo v. Hopkins, 118 U.S. 356, 370 (1886); see also Reynolds v. Sims, 377 U.S. 533, 555 (1964). See generally Wall, Equal Protection: Analyzing the Dimensions of a Fundamental Right-The Right to Vote, 17 SANTA Clara L. REv. 163 (1977); Note, Voter Registration: A Restriction on the Fundamental Right to Vote, 96 YALE L.J. 1615, 1617-28 (1987).

42. The Constitution implicitly protects the "right to vote." U.S. CoNST. art. IV, § 4, cl. 1 (the republican form of government clause). The Constitution explicitly protects the right to vote free from discrimination on the basis of race, id. amend. XV, $\S 1$; on the basis of sex, id. amend. XIX, $\S 1$; by reason of poll taxes, id. amend. XXIV, $\S 1$; or on account of age for citizens who are 18 years of age or older, $i d$. amend. XXVI, $\S 1$.

43. See, e.g., Dunn v. Blumstein, 405 U.S. 330 (1972); Kramer v. Union Free School Dist., 395 U.S. 621 (1969); Williams v. Rhodes, 393 U.S. 23 (1968); Reynolds v. Sims, 377 U.S. 533 (1964); see also Wall, supra note 41, at 164-65.

44. See San Antonio Indep. School Dist. v. Rodriguez, 411 U.S. 1, 35 n.78 (1973) (emphasis added).

45. Dunn v. Blumstein, 405 U.S. 330 (1972) (durational residency requirements unconstitutional); Cipriano v. City of Houma, 395 U.S. 701 (1969) (striking down statute restricting vote to property-owning taxpayers); Harper v. Virginia Bd. of Elections, 383 U.S. 663 (1966) (poll taxes unconstitutional).

46. The equal protection clause reads: "No state shall . . . deny to any person within its jurisdiction the equal protection of the laws." U.S. CoNST. amend. XIV, $\S 1$. Thus, the language of the clause itself seems to call for restraint from misconduct, not for the fulfillment of any affirmative 
lish-only elections. States already provide voting materials to all eligible citizens, but only in English. English-only elections reflect a positive choice that states make to extend voting opportunities only for English speakers. Thus, this Note does not ask the judiciary to require that states provide a new service or benefit; multilingual voting assistance is not a special benefit. While a state is not required to provide every service on an evenhanded basis, the Fourteenth Amendment demands that opportunities to exercise fundamental rights be provided on an equal basis to all eligible citizens unless there is a reason that compels an unequal distribution of rights. ${ }^{47}$ Because the states have chosen to facilitate the right to vote for some it is incumbent on the states to facilitate that right for all.

One lower court has rested its decision on equal protection principles in a case of significance to non-English speakers. The district court in Garza v. Smith ${ }^{48}$ struck down an article of the Texas Constitution that allowed voting assistance only to persons who had "some bodily infirmity, such as renders [them] physically unable to write or to see." 49 The court found that refusal of assistance for illiterate persons violated the equal protection clause by depriving illiterate persons of their fundamental right to vote.

\section{b. No Alternatives Means of Voting}

The Supreme Court's jurisprudence points to an important qualifier to the general rule that voting cases are strictly scrutinized: The Court will not find an infringement of the right to vote if there are alternative means by which the complaining voters could have exercised their voting rights. ${ }^{50}$

duties. This is the equivalent of saying that a state's failure to provide multilingual voting assistance does not constitute "state action." However, given that states do provide assistance in English, failure to provide multilingual assistance should more accurately be termed an "omission," the product of an "active" choice by the state. Cf. Tribe, The Abortion Funding Conundrum: Inalienable Rights, Affirmative Duties, and the Dilemma of Dependence, 99 HARv. L. REv. 330, 331 (1985) (failure to fund abortions for poor women while funding childbirth procedures is "active" choice by government to discourage exercise of individual right).

47. Since the distribution of social services does not implicate rights that the Supreme Court has deemed "fundamental," a state may provide these services unequally as long as there is a "rational basis" for such a distribution. See supra note 33 and accompanying text. Thus, cases denying affirmative benefits to non-English speakers can be distinguished. See Frontera v. Sindell, 522 F.2d 1215 (6th Cir. 1975) (upholding English-only civil service examination); Guerrero v. Carleson, 9 Cal. 3d 808, 512 P.2d 833, 109 Cal. Rptr. 201 (1973) (upholding English-only notices of welfare benefit reductions or terminations), cert. denied sub nom. Guerrero v. Swoape, 414 U.S. 1137 (1974).

48. 320 F. Supp. 131 (W.D. Tex. 1970), vacated on other grounds and remanded, 401 U.S. 1006, remanded, 450 F.2d 790 (5th Cir. 1971).

49. Garza, 320 F. Supp. at 132.

50. This requirement has been applied more often in cases involving the right to equal access to the courts in criminal cases by means of free transcripts or court-appointed attorneys on appeal. See, e.g., Douglas v. California, 372 U.S. 353, 357 (1963) (where indigent defendant has "no recourse" but to prosecute his own appeal, state violated equal protection clause by denying court-appointed counsel); Griffin v. Illinois, 351 U.S. 12, 20 (1956) (state must provide free transcripts to indigent criminal defendants). 
This qualifier indicates the judiciary's unwillingness to provide a remedy if there is a showing by the state that the remedy is unnecessary. ${ }^{51}$

Thus, for example, in McDonald v. Board of Election Commission$e r s,{ }^{52}$ the Gourt held that the denial of absentee ballots to unsentenced inmates of an Illinois county jail did not violate the inmates' voting rights as there was nothing in the record to show that the state had precluded them from voting. Since the state could "possibly furnish the jails with special polling booths . . . or provide guarded transportation to the polls," the Gourt concluded that the "right to vote" had not been infringed and applied a rational relation standard of review to determine whether plaintiffs had a "right to receive absentee ballots."

The Ninth Circuit reviewed a similar claim in Selph v. Council of Los Angeles, ${ }^{54}$ a case brought by physically handicapped persons to require the city of Los Angeles to modify every polling place so as to make them accessible to handicapped people. The court found that the right to vote was not implicated where handicapped voters have reasonable alternatives to voting in person. ${ }^{.5}$

\section{Effective Disenfranchisement}

As the devices used to discriminate against particular individuals in voting have become more sophisticated, the Supreme Court has had to grant relief to voters even when they are not absolutely disenfranchised by the state's actions. In most modern cases, voters find their rights impaired by devices that have the effect of disenfranchising them, even though in the literal sense they are not barred from the polls. ${ }^{\text {bB }}$

There is no set formula for measuring the degree of harm plaintiffs must prove to establish that a state's classification "effectively" disenfranchises them. Drawing on Supreme Court jurisprudence from other fundamental rights areas, as well as voting rights cases, the test applied is whether the classification has a "real and appreciable impact" on the exercise of the protected interest, ${ }^{57}$ such that it unfairly burdens ${ }^{88}$ or penal-

51. See, e.g. Britt v. North Carolina, 404 U.S. 226, 227 (1971) (defendant failed to establish need for transcript in light of court's finding that alternative devices available).

52. 394 U.S. 802 (1969).

53. Id. at 807,808 n.6.

54. 390 F. Supp. 58 (C.D. Cal. 1975).

55. Id. at 62.

56. To the extent that Rosario v. Rockefeller, 410 U.S. 752,757 (1973), suggests that a classification must absolutely bar voters in order to violate the Fourteenth Amendment, that case misinterprets the rest of the Court's jurisprudence regarding degrees of disenfranchisement and stands alone in suggesting that proposition.

In Rosario, the Court held that New York's delayed enrollment scheme that required voters to enroll in a political party eleven months prior to the election simply did not disenfranchise anyone in any way. Id. If newly registered voters failed to register to vote, it was because they "chose not to." Id. at 758. Thus, the Court declined to apply strict scrutiny review.

57. See, e.g., Clements v. Fashing, 457 U.S. 957, 963 (1982); Bullock v. Carter, 405 U.S. 134, 144 (1972).

58. See, e.g., Lubin v. Panish, 415 U.S. 709, 716 (1974). 
izes that interest. ${ }^{80}$ Thus, if the "pratical effect[ ["80 of a state's action is to appreciably impair a fundamental right for certain persons, strict scrutiny is triggered.

Courts have not required that a classification adversely impair the voting rights of all members of the group claiming the disadvantage. Plaintiffs need only show that the classification falls with unequal weight on them. $^{61}$ Thus, the appropriate test for judging the voting rights of nonEnglish speakers is: Does the denial of multilingual elections have a "real and appreciable impact" on the exercise of their voting rights? In other words, does the classification have the practical effect of disenfranchising non-English speakers to a significantly greater degree than English speakers. ${ }^{62}$

\section{B. Equal Protection Claims of Non-English Speakers}

Equal protection doctrine requires that aggrieved voters show that state voting practices disenfranchise them. Thus, non-English speaking voters must show that elections conducted only in English bring about their effective disenfranchisement, thus violating their fundamental right to vote and triggering strict scrutiny. They must also show that there are no alternative means available by which they can exercise this fundamental right. $^{\text {es }}$

In 1970, the California Supreme Court squarely faced the constitutionality of English literacy requirements as applied to non-English speakers in Castro v. State. ${ }^{84}$ The court found that the English literacy requirement of the Galifornia constitution violated petitioners' right to equal protection of the law. However, the Castro decision did not require the state

59. See, e.g., Memorial Hosp. v. Maricopa County, 415 U.S. 250, 257 (1974).

60. Gardner v. California, 393 U.S. 367, 371 (1969).

61. See Bullock v. Garter, 405 U.S. 134 (1972) (voting scheme requiring candidates to pay large filing fees to enter party primaries falls with unequal weight on voters, as well as candidates, according to their economic status).

62. The Supreme Court has made its strongest statements demanding that states respect the equality of each citizen's vote in its legislative apportionment jurisprudence. In this context, the Court has found that states could not draw legislative districts so that there were fewer voters in some districts than in others because that would give greater weight to the votes of citizens in districts of lesser population.

In the landmark apportionment case of Reynolds v. Sims, 377 U.S. 533 (1964), the Court explicitly affirmed the principle that a state's voting scheme need not absolutely disenfranchise a particular group to offend the Constitution. The Court in Reynolds states: "the right of suffrage can be denied by a debasement or dilution of the weight of a citizen's vote just as effectively as by wholly prohibiting the free exercise of the franchise." Id. at 555. In later apportionment cases, the Supreme Court, applying strict scrutiny, has not permitted even de minimis population variations among districts absent compelling justification. See Karcher v. Daggett, 462 U.S. 725, 731 (1983) (de minimis population variation in Congressional districts not allowed absent compelling state interest); Kirkpatrick v. Preisler, 394 U.S. 526, 530-31 (1969) (same); P. BREST \& S. Levinson, Processes OF CONSTITUtional Decisionmaking: Cases and Materials 635 (1983).

63. See supra notes $50-55$ and accompanying text.

64. 2 Cal. 3d 223, 466 P.2d 244, 85 Cal. Rptr. 20 (1970). 
to provide multilingual ballots. Instead the court stated: "The provision of ballots, notices, ballot pamphlets, etc. in Spanish is not necessary either to the formation of intelligent opinions on election issues or to the implementation of those opinions through the mechanics of balloting." ${ }^{\text {"6s }}$ Thus, the only relevant case law assessing constitutionally based voting rights would require non-English speakers to prove that they are effectively disenfranchised by English-only elections in order to obtain a judicial declaration requiring states to provide multilingual assistance.

Nearly twenty years have passed since the California court's decision in Castro. In that time, empirical evidence has been gathered which documents the need for multilingual voting assistance. Further, federal district courts consistently have interpreted the "right to vote" of Spanish speakers under the special 1965 provision to require bilingual ballots for Puerto Rican voters, and Congress has enacted the 1975 amendments to the Voting Rights Act to expand multilingual voting assistance. ${ }^{68}$

\section{Empirical Evidence of Disenfranchisement By Language Barriers}

A recent empirical study, conducted under the auspices of the MexicanAmerican Legal Defense and Education Fund, strongly suggests that English-only elections effectively disenfranchise non-English speakers. The comprehensive 1982 report $^{67}$ was heavily relied upon in the 1982 congressional hearings on the Voting Rights Act. ${ }^{68}$

Conducted in three predominantly Mexican-American communities in Los Angeles, California and Uvalde and San Antonio, Texas, the study concludes that those most likely to be affected by the discontinuance of bilingual voting services are Spanish monolinguals. ${ }^{69}$ Seventy percent of the voting citizens who spoke only Spanish reported that they would be less likely to register and less likely to vote if oral assistance in Spanish

65. Id. at 243,466 P.2d at 282,85 Cal. Rptr. at 34. The court distinguished Lassiter since the appellant in Lassiter made no claim to literacy in any language or to access to news media in another language. The court held that the English proficiency provision discriminated "among literate citizens, disenfranchising all who are literate in languages other than English . . . Id. at 233, 466 P.2d at 250, 85 Cal. Rptr. at 26.

66. See supra notes 21-31 and accompanying text.

67. R. BRISchetro, supra note 24. The report uses archival data including available census, registration and election records collected for the ten previous years. Id. at 16; see also id. at $61 \mathrm{n} .1$ (citing A. Edwards, C. Ortiz \& D. Lopez, 3 Bilingual Election Services: A State of the ART REPORT (1979)); id. at 34 n.1 (citing Cooper \& Greenfield, Language Use and the Bilingual Community, 53 MOD. Language J. 166 (1969)). The report is based on secondary analysis of existing survey data, including that contained in the Census Bureau Survey of INCOME AND EducaTION (1976) and the National Chicano SuRvey (1979), which was conducted at the University of Michigan. Id. at 4.

68. See S. Rep. No. 417, 97th Cong., 2d Sess. 66, reprinted in 1982 U.S. Code ConG. \& ADMIN. News 244-45.

69. R. BRIschetTo, supra note 24 , at 49 . The following results bear out this conclusion: 
were discontinued. ${ }^{70}$ Seventy-two percent indicated they would be less likely to vote if the bilingual ballot were discontinued. ${ }^{71}$

\section{Judicial Acknowledgment of the Need for Multilingual Voting As- sistance for Non-English Speakers}

The Voting Rights Act of 1965 includes a provision protecting Puerto Rican citizens who emigrate to the mainland from language discrimination in voting. ${ }^{72} \mathrm{~A}$ series of cases point to this provision for support for the proposition that ballots printed only in English deny non-English speakers the right to vote. Those cases construing section 4(e) of the Voting Rights Act of 1965 consistently hold that the "right to vote" entails more than a right of equal access to ballots in English-it requires equal access to ballots in a language the voter can understand. While these cases do not directly bear on the constitutionality of English-only elections, they do support the proposition that English-only elections deny non-English speakers any meaningful opportunity to exercise their voting rights.

In enacting this special provision protecting Puerto Rican citizens, Con-

Probable Effect of Removal of Bilingual Services by Language Ability

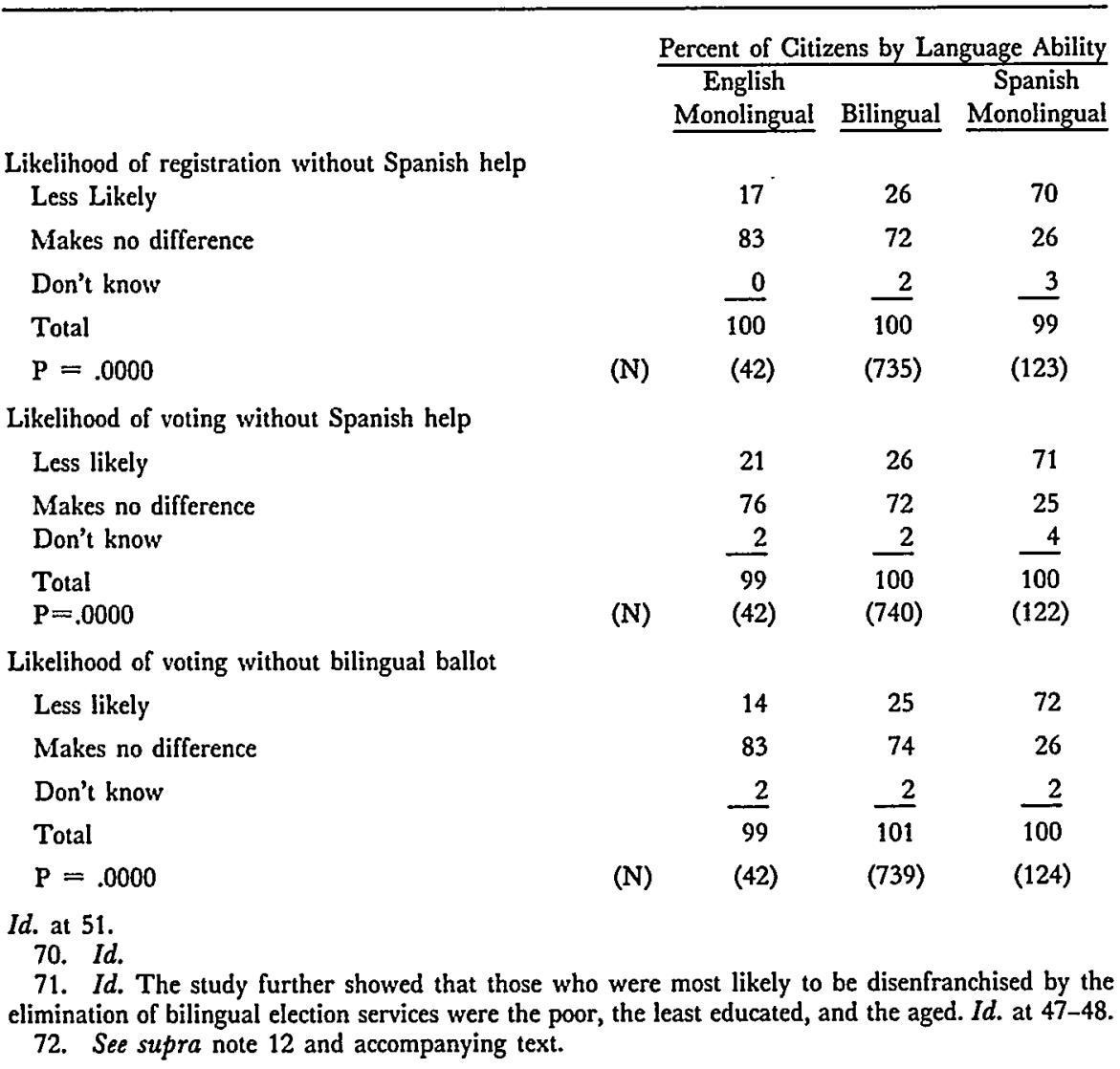


gress declared only that the states could not condition the right to vote on English proficiency; it did not specify that the states should provide multilingual ballots. Nonetheless, the courts have recognized that the right to vote includes the right to understand the vote one is casting and accordingly have required multilingual materials and assistance.

The Seventh Circuit in Puerto Rican Organization for Political Action v. Kusper" found the right to vote to include "the right to be informed as to which mark on the ballot, or lever on the voting machine, will effectuate the voter's political choice." "74

The Pennsylvania District Court in Arroyo v. Tucker ${ }^{75}$ agreeing with the reasoning of Kusper and its progeny, stated that "'the right to vote' means more than the mechanics of marking a ballot or pulling a lever."76 Non-English speakers cannot cast an effective vote "without ... [the] ability to comprehend the registration and election forms and the ballot itself." "77

In short, every lower court that has interpreted the statutory right that prohibits states from conditioning the right to vote of Puerto Rican citizens on an ability to understand English ${ }^{78}$ has concluded that that right, by force of reason, must entail voting assistance in a language the voter understands.

\section{State Interests and the Means Employed to Achieve Them}

State action that infringes on fundamental rights is presumptively illegitimate. ${ }^{79}$ Under the so-called "strict scrutiny" standard of review, a state must show that the action advances legitimate and "compelling" state objectives. The state must then show that the choice of means are best suited to the stated ends. ${ }^{80}$

73. 490 F.2d 575, 579 (7th Cir. 1973).

74. Id. (citing Garza v. Smith, 320 F. Supp. 131, 136 (W.D. Tex. 1970)). Similarly, in Torres v. Sachs, 381 F. Supp. 309 (S.D.N.Y. 1974), the district court held: "In order that the phrase "the right to vote' be more than an empty platitude, a voter must be able effectively to register his or her political choice. . . "Id. at 312. The court in Torres found that all-English elections violated not only the Voting Rights Act language provision, but the Fourteenth Amendment as well.

75. 372 F. Supp. 764 (E.D. Pa. 1974) (holding that Philadelphia's English-only election system infringed Puerto Rican voters right to vote under $\$ 4(e)$ of the Voting Rights Act).

76. Id. at 767 .

77. Id. Other decisions, interpreting the 1965 Act, further develop the idea that persons who do not read or write English have a right to cast an effective ballot. United States v. Louisiana, $265 \mathrm{~F}$. Supp. 703, 708 (E.D. La. 1966) (statute denying illiterates voting assistance was literacy test violating the Voting Rights Act) ("We cannot impute to Congress the self-defeating notion that an illiterate has the right [to] pull the lever of a voting machine, but not the right to know for whom he pulls the lever."); United States v. Mississippi, 256 F. Supp. 344 (S.D. Miss. 1966) (defining "vote" as "any and all action necessary to make a vote effective in any ... election ... [including] casting a ballot").

78. See supra note 12 and accompanying text.

79. See supra notes $38-40$ and accompanying tes:t.

80. See, e.g., Zablocki v. Redhail, 434 U.S. 374 (1978) (state interests were "legitimate and substantial ... but, since the means selected ... unnecessarily impinge on the right to marry, the statute cannot be sustained"). 


\section{Promotion of a Unilingual Government}

In justifying their position, the proponents of English-only elections point to the state's compelling interest in a unilingual government ${ }^{81}$ and the possibility that the accommodation of non-English speakers could result in a bilingual or trilingual nation. ${ }^{82}$ Even assuming that a state language policy is constitutional and that the voting machinery is a constitutionally permissible means by which to implement it, equal protection analysis requires that English-only. elections must be the least restrictive means of creating a unilingual government. There is no proof that English-only elections encourage or promote the learning of English. Elections take place only once every year or two, thereby not directly affecting individual non-English speakers regularly enough to encourage the learning

81. The unfairness of state action that penalizes non-English speakers in order to promote a unilingual government lies in the fact that the de jure and de facto school segregation of language minority children in public schools has contributed to the retention of the groups' mother tongues and has hindered the acquisition of English skills. See Laosa, Social Policies Toward Children of Diverse Ethnic, Racial and Language Groups in the United States, in Child Development Research AND Social Policy 1 (H. Stevenson \& A. Siegel eds. 1984); see also Hernandez v. Texas, 347 U.S. 475, 479 (1954) (noting segregation of Mexican-American children and white children in public schools); Gaston County v. United States, 395 U.S. 285, 289 (1969) (recognizing causal relationship between unequal educational opportunities and exercise of right to vote of racial minorities); $c f$. Lau v. Nichols, 414 U.S. 563 (1974) (failure to provide English language instruction to non-English speaking Chinese-American students violates Civil Rights Act of 1964). See generally J. FishmaN, LANGUAge Loyalty in THE United States (1966) (discussing language retention by United States immigrant groups).

82. They consider this to be an undesirable possibility. See Hayakawa, English, By Law, N.Y. Times, Oct. 1, 1981, at A35, col. 2 ("The longer they [non-English-speaking children] are instructed in the native tongue [through bilingual education programs], the more difficult it becomes for them to learn English in their later years. . . The use of bilingual ballots compounds the problem.") (Remark of the Honorary Chairman of U.S. English, former Senator Hayakawa); $c f$. Bikales, Make English Official by Passing New Laws, U.S.A. Today, Apr. 10, 1985, at 8A, col. 1 ("But things are different today, and we can no longer assume that recent arrivals will automatically follow a path leading to their uneventful insertion into U.S. society.") (Remark by G. Bikales, Executive Director of U.S. English); Fundraising letter for English First from J. Horn, Texas State Representative (1986) ("Tragically, many immigrants these days refuse to learn English!") (on file with author); see also Guadalupe Org. v. Tempe Elem. School Dist. No. 3, 587 F.2d 1022, 1027 (9th Cir. 1978) (citing linguistic and cultural diversity as source of weakness for nation-state).

The view that recent Mexican immigrants are not learning English as rapidly as did other prior immigrant groups has been refuted by a recent Rand Corporation study, K. MCCARTHY \& R. Burciaga Valdez, CuRrent and Future Effects of Mexican Immigration in California (1986). The research found that persons of Mexican origin are making essentially the same progress of integration as earlier European immigrants and as the state's recent Asian immigrants. Id. at 54-55. The study also examined the transition of Spanish speakers to English, concluding that most of the first-generation native-born are bilingual, and more than $90 \%$ are proficient in English. Among the second-generation, more than half are monolingual English speakers. Thus, the transition to English is almost immediate. Id. at 60; see also English Courses: Immigrants-a Rush to the Classrooms, L.A. Times, Sept. 24, 1986, at 1, col. 1 (In the Los Angeles Unified School District alone, officials estimate that 40,000 adults will be turned away from English as a second language (ESL) classes in 1986.). 
of English. ${ }^{83}$ On the contrary, the direct effect on disenfranchised individuals is likely to be their further alienation from the political process. ${ }^{84}$

Further, the deprivation of voting rights increases the possibility that, as a group, non-English speakers who already suffer economic disadvantages because of their linguistic handicap will also suffer political disadvantages because of their lack of representation. ${ }^{85}$ They will be less likely to receive government benefits such as social services and educational facilities which are meted out by political representatives. ${ }^{86}$ Since the availability of such benefits is widely recognized as essential to a group's ability to assimilate, English-only elections are more likely to slow the process of assimilation, rather than to "encourage" it. ${ }^{87}$

\section{The Costs of Multilingual Elections}

A state may argue that multilingual ballots and assistance are prohibitively costly, thus justifying the provision of ballots only in English. Cost efficiency, however, has not been accepted by the judiciary as a compelling governmental interest sufficient to survive even an intermediate degree of scrutiny ${ }^{88}$

Assuming arguendo that a court were to scrutinize the costs of multi-

83. See Sierra v. El Paso Indep. School Dist., 591 F. Supp. 802, 807 (W.D. Tex. 1984) (finding lingering effects of past official discrimination in form of poll tax and English-only ballots deterred Mexican-Americans from registering, voting, and otherwise participating in political process); see also Rome v. United States, 446 U.S. 156, 176 (1980) (addressing alienating effects of discriminatory voting practices); Graves v. Barnes, 378 F. Supp. 640 (W.D. Tex. 1974) (examining discriminatory impact of multi-member districts on Mexican-American access to political process); Karst, Paths to Belonging: The Constitution and Cultural Identity, 64 N.C.L. REv. 303, 332-36 (1986).

84. Karst, supra note 83 , at $332-36$.

85. Disenfranchisement of non-English speakers deprives them of a vital instrument for change through the political process and points to the need for the special judicial protection granted to "discrete and insular" minorities. See generally supra note 33; J. ELY, supra note 38.

86. Katzenbach v. Morgan, 384 U.S. 641, 652 (1966) ("Section 4(e) may be viewed as a measure to secure for the Puerto Rican community residing in New York non-discriminatory treatment by government-both in the imposition of voting qualifications and the provision or administration of governmental services, such as public schools, public housing and law enforcement."); see also Karst, supra note 83 , at 334 .

87. This argument assumes that the best interests of non-English speakers are served by assimilation. While both English-only supporters and opponents agree that non-English speakers are better off if they learn English, some racial and ethnic groups have in the last few decades asserted their rights to maintain their native tongues while becoming proficient in English. See, e.g., Karst, supra note 83, at 337; Comment, Cultural Pluralism, 13 HARv. C.R.-C.L. L. REv. 133 (1978). Moreover, discrimination in the choice of language deprives a person of human dignity by distorting one's conception of identity. McDougal, Lasswell \& Chen, Freedom from Discrimination in Choice of Language and International Human Rights, 1 S. IL... U.L.J. 151, 151-52 (1976).

88. See Frontiero v. Richardson, 411 U.S. 677, 689-90 (1973) (administrative convenience does not outweigh female military persons' equal protection rights to equal treatment). In Carrington v. Rash, 380 U.S. 89, 96 (1965), the Court rejected the state's claims that denying the vote to persons in the Army promoted administrative efficiency: "States may not casually deprive a class of individuals of the vote because of some remote administrative benefit . . . ."; see also Shapiro v. Thompson, 394 U.S. 618, 633 (1969) ("The saving of welfare costs cannot justify an otherwise invidious classification."); Memorial Hosp. v. Maricopa County, 415 U.S. 250, 263 (1974) ("The conservation of the taxpayers' purse is simply not a sufficient state interest to sustain a durational residency requirement which, in effect, severely penalizes exercise of the right [to travel]."); Rivera v. Dunn, 329 F. Supp. 554 (D. Conn. 1971), aff d, 404 U.S. 1054 (1972) (same). 
lingual ballots, the relevant equal protection question to ask with respect ${ }^{\circ}$ to costs is not how much more a state would have to spend to provide multilingual assistance, but how much is already spent per voter to provide English ballots and whether the comparative costs of multilingual voting would be so excessive as to override a fundamental right. ${ }^{80}$ The information available on costs, however, looks to the question of incremental rather than comparative costs. There is a tendency to focus only on the costs of multilingual ballots, without taking into consideration the costs of English ballots; the amount of money spent per English-speaking voter has apparently never seemed relevant.

Nevertheless, the data does suggest that the cost of multilingual ballots are only a small percentage of total election expenses. A study by the General Accounting Office reports that the additional costs incurred by 83 jurisdictions that provided bilingual ballots which had record of such costs were $7.6 \%$ of the total costs to these jurisdictions to hold the November 4, 1984 election. ${ }^{90}$ In 259 of the jurisdictions surveyed by the General Accounting Office which provided oral assistance, no costs were incurred.91 Thus, available data strongly suggests that the costs of providing multilingual voting assistance fall within the range of expenditures that can be compelled. ${ }^{92}$

Furthermore, Congress was clearly not concerned that multilingual elections were excessively costly. ${ }^{93}$ One might assume that the use of the

89. Many people express an instinctive worry that a constitutional rule that requires states to provide multilingual voting assistance to every non-English speaker would be excessively costly and administratively burdensome in areas with only a few non-English speakers. As with most constitutional requirements, however, states would have the flexibility to develop systems for identifying voters needing the assistance and for implementing the multilingual system. Courts should nonetheless place a heavy burden on the states to accomodate every voter needing assistance unless such accommodation would be clearly unreasonable. For example, if there were only one person within a 500 mile radius that needed assistance, and no one was available in that area to interpret the ballot, assistance might not be a reasonable demand on the state.

90. GAO REPORT, supra note 25 , at 19 .

91. Id. at 18. Moreover, the growing use of multilingual voting assistance has caused costs to decline over time, due to "better targeting of materials, and more reliance upon translations and materials used in prior elections." S. REP. No. 417, 97th Cong., 2d Sess. 65, reprinted in 1982 U.S. Code Cong. \& ADMIN. News 243-44. The Senate Report also notes the dramatically decreased costs in Los Angeles from 1976 to 1980, the 1980 figure constituting only 1.9 percent of the total general election budget. Id.

92. Id. As the need for multilingual election materials has grown, the economies of scale involved in the production of these materials has fallen, thus reducing the costs to individual counties. See GAO REPORT, supra note 25 , at 25 . Additionally, for small counties oral voting assistance may be provided at almost no cost as most interpreters volunteer their service gratuitously. Id. at 18 . Finally, firms in the voting materials industry are exploring the possibilities for computerized voting machines. VoTing System Standards, a Report to Congress on the Development of Voluntary Engineering and Procedural Performance Standards for Voting Systems (1984). Such advanced technology could dramatically reduce the costs of providing written multilingual services, making it clearly unreasonable not to provide such services.

93. The Senate Judiciary Committee strongly refuted the "excessive costs" arguments with empirical evidence and further concluded: "Even if the costs of bilingual elections were higher . . . the Committee believes that certain costs should be willingly incurred to make our most fundamental political rights a reality for all Americans." S. REP. No. 417, 97th Cong., 2d Sess. 65, reprinted in 1982 U.S. Code Cong. \& Admin. News 244. 
five percent trigger was intended as a cost-minimizing device. In fact, Congress used the five percent mark to identify areas where federal statutory intrusion was most needed so as not to interfere in states' decisions on voting procedures unless the situation rose to a level where federal action was warranted. ${ }^{94}$

Admittedly, states cannot provide voting materials without discriminating, or drawing lines, at some point. Within a constitutional framework, the states must have discretion in the operation of voting facilities and in the printing of ballots and other materials. However, states have an overriding obligation to provide voting opportunities on an evenhanded basis to all citizens and to extend meaningful voting assistance to non-English speakers.

\section{Policy Suggestions}

In communities with non-English speaking groups, the logistics involved in operating the voting process may become complicated. Thus, Congress might consider changing the multilingual voting provisions of the Voting Rights Act to replace the percentage trigger with a numerical trigger and to expand coverage to all non-English speakers. For example, instead of requiring multilingual elections in areas that meet the five percent requirement, the Act should be triggered in areas with, say, 1,000 non-English speakers. In areas with fewer than 1,000 non-English speakers, the states should be required to make reasonable efforts to provide assistance, either written or oral. States might be required to inquire about the voters' needs for language assistance at registration, for instance. However, the burden of notifying election officials of one's need for assistance should probably rest with the voter where there is no large, established non-English speaking community that triggers the Act. Community ethnic leagues could serve as liasons with the state to facilitate this communication. In short, multilingual elections should involve extensive communication and cooperation between state officials and community members.

94. A cost minimizing rationale for the five percent trigger is mentioned nowhere in the legislative history. See Extension of the Voting Rights Act: Hearings Before the Subcomm. on Civil and Constitutional Rights of the House Comm. on the Judiciary, 94th Cong., 1st Sess. 84 (1975) [hereinafter 1975 House Hearings] (statement of Rep. Jordan); id. at 573 (statement of Mr. Pottinger); 9111 Cong. Rec. S1279 (daily ed. Apr. 7, 1975) (statement of Sen. Bayh).

Representatives Roybal and Badillo lifted the five percent trigger from lower court decisions in Arroyo v. Tucker, 372 F. Supp. 764 (E.D. Pa. 1974) and Torres v. Sachs, 381 F. Supp. 309 (S.D.N.Y. 1974). 1975 House Hearings, supra, at 884, 934. These decisions required bilingual ballots and materials for all Puerto Rican voters, but required bilingual election officials only in election districts in which Puerto Rican voters constituted at least five percent of the voting population. $A r$ royo, 372 F. Supp. at 768; Torres, 381 F. Supp. at 313. 


\section{GonClusion}

Courts have been deeply involved in extending the franchise to marginal groups that majoritarian processes exclude. A representative democracy mandates that every adult citizen have a voice in the future of the polity. ${ }^{95}$ If courts gave the voting rights of non-English speakers federal constitutional protection, the states and Congress could better address themselves to the vindication of those rights. Additionally, through further amendment of the Voting Rights Act, Congress can most efficiently implement federal policies that protect language minorities from disenfranchisement, eliminating the need for individual state legislation. A judicial determination that the prohibition of multilingual voting assistance violates the constitutional rights of non-English speakers would firmly establish a state or national language policy that incorporates, rather than excludes, speakers of all languages into one cohesive body politic.

95. Professor Karst points to two fundamental values encompassed in rights of citizenship: protection of human dignity and self-respect, and protection of avenues for participation in the decisionmaking processes of the community. Karst, The Supreme Court, 1976 Term-Foreword: Equal Citizenship Under the Fourteenth Amendment, 91 HARv. L. REv. 1, 23 (1977). In another piece he says that respect for rights of citizenship:

promote[s] the freedom of individual choice about cultural identification. . . . When the promise of equal citizenship is fulfilled, the paths to belonging are opened in two directions for members of cultural minorities. As full members of the larger society, they have the option to participate to whatever degree they choose. They may also look inward, seeking solidarity within their cultural groups, without being penalized for that choice. Karst, supra note 83, at 337. 
